\title{
The Demand Performance of Bus Rapid Transit
}

\author{
Graham Currie, Monash University
}

\begin{abstract}
This article uses a trip attribute approach to examine the relative passenger attractiveness of Bus Rapid Transit (BRT) systems compared to other transit modes. It examines how passengers value trip attributes for on-street bus, BRT, and light rail and heavy rail systems in passenger behavior research. Empirical data is presented which suggests that passengers value trip attributes for BRT and rail modes in a broadly similar manner. All of these transit modes are favored relative to on-street bus. These findings suggest that BRT systems should be as effective as rail in generating patronage when developed to replace on-street bus services. This conclusion, in association with research demonstrating lower costs for BRT systems compared to rail, may be used to claim cost effectiveness advantages for BRT. However, a number of limitations in the evidence are identified and additional research suggested. Conclusions of the research are also used to suggest ways to improve BRT system design to enhance demand performance.
\end{abstract}

\section{Introduction}

Bus Rapid Transit (BRT) is now a major trend in the development of public transport systems worldwide. While BRT has been shown to have lower implementation costs compared to other transit modes (General Accounting Office 2001), its cost effectiveness can only be assessed by examining its relative performance in generating demand compared to other transit modes. 
This article explores the relative passenger attractiveness of BRT systems compared to other transit modes by studying trip attribute research evidence. It examines how passengers value trip attributes for on-street bus, BRT, light rail and heavy rail systems in passenger behavioral research and modeling. The article includes:

- a summary of trip attribute research

- an analysis of trip attributes that vary between modes

- an assessment of what the results suggest for the relative attractiveness of BRT compared to other transit modes

\section{Transit Trip Attributes}

Figure 1 shows the key components of a typical trip by public transport.

\section{Figure 1. Trip Attributes in Typical Transit Journey}

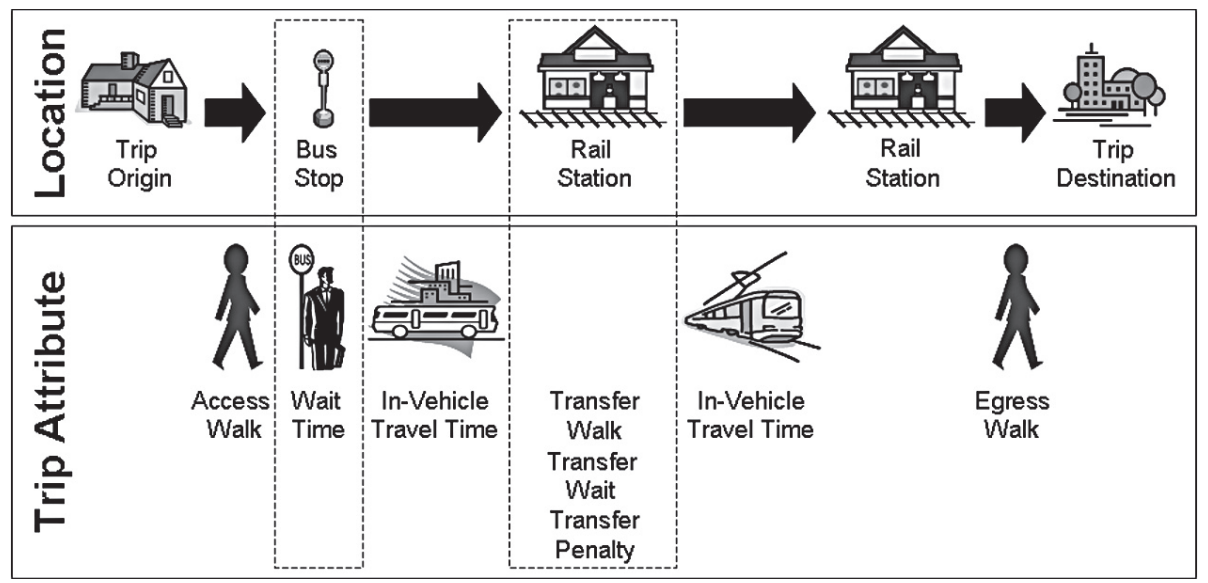

The measurement of how passengers value each of these trip attributes is an important input to disaggregate transport modeling and a major driver of travel demand forecasts for the development of new public transport modes. The quality of travel is measured in terms of generalized cost using a formula of the following type: 
$T G C=\left(\left(\right.\right.$ Walk $_{t} *$ Walk $\left._{w}\right)+\left(\right.$ Wait $\left.\left._{t} * W_{a i t_{w}}\right)+\left(I V T_{t} * I V T_{w}\right)+(N T * T P)+M S C_{m}\right) * V O T+$ Fare

where:

$\begin{array}{ll}\text { Walk }_{t} & \text { equals time in minutes walking to and from the transit service } \\ \text { Walk }_{w} & \text { is passenger valuation of walk time to and from transit stops } \\ \text { Wait }_{t} & \begin{array}{l}\text { measures time waiting for transit vehicle to arrive at the transit } \\ \text { stop }\end{array} \\ \text { Wait }_{w} & \text { indicates passenger valuation of wait time at transit stops } \\ \text { IVT }_{t} & \text { shows travel time in transit vehicle/s } \\ \text { IVT }_{w} & \text { is passenger valuation of in vehicle travel time } \\ \text { NT } & \text { equals number of transfers } \\ \text { TP } & \text { is transfer penalty } \\ \text { MSC } & \text { equals mode specific constant for transit mode } m \\ \text { VOT } & \text { measures value of travel time } \\ \text { Fare } & \text { is average fare per trip }\end{array}$

Primary research measures the values for each of these trip attributes to establish the impacts of new transport investments such as introducing new transit modes. Clearly, modes that have higher perceived generalized cost perform poorly in patronage terms against those with lower values.

It is a central premise of this article that the patronage performance of BRT can best be understood through measurement of how passengers value trip attributes specific to BRT systems. A comparison of how perceived BRT attribute values compare against those of other transit modes will be indicative of their relative patronage performance.

\section{Trip Attribute Research and Transit Modes}

Table 1 divides trip attributes into transit mode neutral and transit mode specific elements based on the degree to which passengers might value the attributes differently for alternative public transport modes. 
Table 1. Mode Specific and Mode Neutral Public Transport Trip Attributes

\begin{tabular}{|l|l|}
\hline Trip Attribute & Description \\
\hline Transit Mode Neutral Trip Attributes \\
\hline Access walk & Walk from trip origin to transit stop/station \\
\hline Egress walk & Walk from alighting stop to trip destination \\
\hline Wait time & Time at transit stop/station waiting for transit vehicles to arrive \\
\hline Fare & Price of ticket to use service \\
\hline $\begin{array}{l}\text { In-vehicle travel } \\
\text { time }\end{array}$ & Time spent in transit vehicle traveling from boarding stop to alighting stop \\
\hline Transit Mode Specific Trip Attributes \\
\hline Transfer penalty & $\begin{array}{l}\text { Perceptual value of the need to transfer between one transit vehicle to } \\
\text { another }\end{array}$ \\
\hline $\begin{array}{l}\text { Mode-specific } \\
\text { factors }\end{array}$ & Other factors perceived by passengers to vary with transit mode \\
\hline
\end{tabular}

It is a common convention in mode choice modeling to make no distinction between transit modes in the measurement of walk and wait time, fare, or invehicle travel time (see, for example, Wardman 1997 and Transfund New Zealand 2000).

The research literature also contains many examples in which these trip attributes are measured for several transit modes as a group. Van der Waard (1988), Prosser et al. (1997), and Gwilliam (1999) all quote coefficients for walk and wait times that are aggregates of behavioral evidence from bus, tram, and heavy rail. They are applied to bus, tram, or heavy rail separately, suggesting no expected difference in how a passenger values them between modes.

Public transport fares could vary by transit mode depending on the fares policy and funding approaches of urban transport planning agencies. For purposes of this article, we have assumed fares to be mode neutral since it is the intrinsic differences in the qualities of transit modes that are of interest, not funding policy differences.

Trip attribute factors that are considered to be mode specific include the transfer penalty and mode-specific factors. 


\section{Transit Mode Specific Trip Attributes \\ Transfer Penalties}

The transfer penalty is the perceived value of making a transfer between one public transport vehicle and another. It is the value in addition to any time spent undertaking a walk or wait to complete a transfer. Transfer penalty is expressed as a constant value, usually in terms of minutes of equivalent in-vehicle travel time.

Table 2 shows a range of evidence on the valuation of transfer penalties by transit mode. Although there is much scatter in the data, it is clear that bus-based modes have generally far higher valuations of transfer penalties compared to rail-based modes. The average of the range of bus-bus based transfers is around 22 minutes, which compares with a value for subway-based heavy rail systems of around 8 minutes.

These results might be suggestive of a relatively poor rating for transfers for BRT compared to rail-based modes. However, none of this evidence includes values measured for BRT systems. ${ }^{1}$ None could be found in the literature. The bus-based data in Table 2 concerns on-street bus services. Collection of transfer penalties for BRT systems is clearly a research priority. Nevertheless, the data in Table 2 suggest how BRT might perform.

Table 2 shows that transfer penalties are lower for transit modes that have higher quality interchange facilities such as stations, platforms, and protected walkways. Underground subways, which include weather protection, a range of passenger amenities, and facilities such as escalators, tend to have lower transfer penalties. On-street bus services where transfers include waiting in the open air, limited passenger facilities, and can involve crossing roads to complete transfers have higher transfer penalties. These findings are supported by a range of other evidence. For example, Horowitz and Thompson (1994) found that the design of transfer locations could significantly alter passenger perceptions of the transfer penalty. They suggest that the provision of weather protection at transfer locations could benefit passengers by as much as 16 minutes of perceived in-vehicle travel time.

Although a lack of data on transfer penalties is not helpful in establishing BRT's position in relation to other modes, patterns in the available data suggest that BRT should perform well compared to rail-based transit. The development and design of significant station infrastructure is a central theme of BRT-based planning. For example, the Transit Cooperative Research Program (2003a) identifies station infrastructure as a major characteristic of BRT system design. Significant station 
Table 2. Evidence of Transfer Penalty by Transit Mode (Minutes of equivalent in-vehicle travel time)

\begin{tabular}{|c|c|c|c|c|c|c|c|}
\hline \multirow[b]{2}{*}{ Source } & \multirow[b]{2}{*}{ Location/ Case } & \multicolumn{6}{|c|}{ Transit Modes } \\
\hline & & $\begin{array}{l}\text { Bus- } \\
\text { Bus }\end{array}$ & Bus- LRT & $\begin{array}{l}\text { Bus- } \\
\text { Suburban } \\
\text { Rail }\end{array}$ & $\begin{array}{c}\text { Suburban } \\
\text { Rail- } \\
\text { Suburban } \\
\text { Rail }\end{array}$ & $\begin{array}{c}\text { Suburban } \\
\text { Rail- } \\
\text { Subway }\end{array}$ & $\begin{array}{l}\text { Subway- } \\
\text { Subway }\end{array}$ \\
\hline \multirow{6}{*}{$\begin{array}{l}\text { Charles River } \\
\text { Associates } \\
(1989)^{1}\end{array}$} & $\begin{array}{l}\text { Chicago/Work } \\
\text { Trips }\end{array}$ & $18-37$ & & & & & \\
\hline & Boston/All Trips & & $15-28$ & & & & \\
\hline & Ottawa/All Trips & $22 \cdot 30$ & & & & & \\
\hline & $\begin{array}{l}\text { Edmonton/All } \\
\text { Trips }\end{array}$ & & $12-25$ & & & & \\
\hline & $\begin{array}{l}\text { Honolulu/All } \\
\text { Trips }\end{array}$ & 6 & & & & & \\
\hline & Taipei/All Trips & 30 & & & & & \\
\hline $\begin{array}{l}\text { British } \\
\text { Railways } \\
(1989)^{1} \\
\end{array}$ & $\begin{array}{l}\text { London/All Urban } \\
\text { Trips }\end{array}$ & & & & & $10-14$ & \\
\hline Ryan (1996)' & London & & & & & 5 & $4^{3}$ \\
\hline $\begin{array}{l}\text { Standeby } \\
(1993)^{1}\end{array}$ & Oslo & $8-10$ & & & & & \\
\hline $\begin{array}{l}\text { Piotrowski } \\
(1993)^{1}\end{array}$ & Perth/Work Trips & 8 & & 6 & & & \\
\hline $\begin{array}{l}\text { Prosser et al. } \\
(1997)^{1}\end{array}$ & Sydney/A.M. Peak & & & 11 & 6 & & \\
\hline $\begin{array}{l}\text { Algers et al. } \\
(1975)^{2}\end{array}$ & Stockholm & 50 & & 23 & 15 & & $4^{3}$ \\
\hline Hunt $(1990)^{2}$ & Edmonton & & 18 & & & & \\
\hline $\begin{array}{l}\text { Wardman et } \\
\text { al. }(2001)^{2}\end{array}$ & Edinburgh & 5 & & & 8 & & \\
\hline $\begin{array}{l}\text { Guo and } \\
\text { Wilson (2004) }\end{array}$ & Boston/All Trips & & & & & & $2-32^{3}$ \\
\hline & Average of values & 22 & 19 & 13 & 10 & 9 & 8 \\
\hline & Range of values & 5 to 50 & 12 to 28 & 6 to 23 & 6 to 15 & 5 to 14 & 1 to 32 \\
\hline
\end{tabular}

1This data sourced from Transfund New Zealand (2000).

${ }^{2}$ This data sourced from Guo and Wilson (2004).

${ }^{3}$ Lower values are explained by short/no walk transfers and cross platform transfers.

Note: All values are rounded to the nearest minute 
infrastructure is identified as a feature of some 21 of the 26 BRT systems examined in the Transit Cooperative Research Program (2003b).

While the above data suggest that BRT systems will have transfer penalties similar to rail-based modes, some caution is required due to lack of primary evidence. In addition Guo and Wilson (2004) have presented evidence that transfer penalties can vary because of the way they are measured. Bus to bus transfer penalties of 4.5, 30 , and 49.5 minutes are quoted and shown to derive from alternative approaches to their measurement as well as from different bus systems. Clearly, there is a need for a consistent approach to measurement of transfer penalties as well a need to increase research coverage in relation to BRT systems.

\section{Mode-Specific Factors}

The Mode Specific Factor (MSF) is the user-perceived attractiveness of one transit mode compared to another, excluding the influence of factors such as fare, walk time, wait time, in-vehicle travel time, and the need to transfer. The MSF is usually measured as a constant and expressed in minutes of equivalent in-vehicle travel time. The following quote personifies one view of the MSF:

Many studies have found that, other things being equal, most public transport users prefer rail to bus because of its greater comfort. To model this choice accurately, a penalty of four to six minutes must often be attached to bus travel to reflect the relative discomfort of buses. Abelson (1995) quoting Fouracre et al. (1990)

In this case the reference to bus concerns on-street services rather than BRT. Table 3 shows a summary of evidence of the MSF measured in a range of studies. The value of the MSF for heavy rail, light rail, and BRT is indicated. In each case the MSF is expressed as the value of the difference of the transit mode relative to on-street bus. A positive value represents a preference to the transit mode. A negative value represents a preference to on-street bus.

A range of values emerge from Table 3:

- In general, heavy rail is preferred over on-street bus with the value of preferences ranging between 2 minutes and 33 minutes. However, there are a small number of negative values $(-5,-27$, and -56 minutes). There is an overall average of about 4 minutes preference to heavy rail. 


\section{Table 3. Evidence of Mode-Specific Constants by Transit Mode (Minutes of equivalent in-vehicle travel time)}

\begin{tabular}{|c|c|c|c|c|}
\hline \multirow[b]{2}{*}{ Source } & \multirow[b]{2}{*}{ Location/ Case } & \multicolumn{3}{|c|}{ Transit Modes } \\
\hline & & $\begin{array}{c}\text { Bus Rapid } \\
\text { Transit vs. } \\
\text { On-Street Bus }\end{array}$ & $\begin{array}{c}\text { Light Rail } \\
\text { vs. } \\
\text { On-Street Bus }\end{array}$ & $\begin{array}{l}\text { Heavy Rail } \\
\text { vs. } \\
\text { On-Street Bus }\end{array}$ \\
\hline \multirow{2}{*}{ Halcrow Fox $(1995)^{1}$} & $\begin{array}{l}\text { Manchester/Car Available } \\
\text { Passengers }\end{array}$ & & 20 & \\
\hline & $\begin{array}{l}\text { Manchester/Car Not } \\
\text { Available Passengers }\end{array}$ & & 0 & \\
\hline $\begin{array}{l}\text { Bray (1995)/Transfund NZ } \\
(2000)^{1}\end{array}$ & Adelaide/All Trips & 20 & & \\
\hline $\begin{array}{l}\text { Ableson (1995)/Fouracre } \\
\text { et al. }(1990)^{1}\end{array}$ & International/All Trips & & & $4-6$ \\
\hline Van Der Waard (1988) ${ }^{1}$ & Holland/All Trips & & $2-3$ & $2-3$ \\
\hline Kilvington $(1991)^{1}$ & $\begin{array}{l}\text { UK Several Studies/Car } \\
\text { Available Passengers }\end{array}$ & 9 & 15 & 12 \\
\hline Kilvington $(1991)^{1}$ & Dublin/Bus Users & 12 & 16 & 16 \\
\hline London Railplan Review ${ }^{1}$ & UK Several Studies/Bus Users & 9 & 8 & 7 \\
\hline Prosser et al. (1997) ${ }^{1}$ & Sydney/A.M. Peak & & 4 & 9 \\
\hline \multirow{16}{*}{ Wardman $(1997)^{2}$} & Study 19 (B) 1989 & & & -56 \\
\hline & Study 19 (B) 1989 & & & -27 \\
\hline & Study 7 (B) 1992 & & & -5 \\
\hline & Study 4 (B) 1993 & & & 0 \\
\hline & Study 17 (B) 1987 & & & 0 \\
\hline & Study 8 (B) 1988 & & & 3 \\
\hline & Study 20 (B) 1989 & & & 4 \\
\hline & Study 20 (B) 1989 & & & 6 \\
\hline & Study 3 (B) & & & 10 \\
\hline & Study 28 (B) 1989 & & & 11 \\
\hline & Study 28 (B) 1989 & & & 11 \\
\hline & Study 4 (B) 1993 & & & 22 \\
\hline & Study 23 (B) 1990 & & & 33 \\
\hline & Study 13 (B) 1991 & & 1 & \\
\hline & Study 9 (B) 1989 & & 10 & \\
\hline & Study 12(B) 1990 & & 18 & \\
\hline \multicolumn{2}{|r|}{ Average of values } & 12 & 10 & 4 \\
\hline \multicolumn{2}{|r|}{ Range of values } & 9 to 20 & 2 to 20 & .56 to 33 \\
\hline
\end{tabular}

1 This data sourced from Transfund New Zealand (2000).

${ }^{2}$ The Wardman (1997) evidence is from a series of confidential consultancies studies that are quoted via a code number for reference purposes.

Note: All values are rounded to the nearest minute 
- All MSF values for light rail showed a preference of light rail over on-street bus ranging from 2 to 20 minutes. The average of the values shown is around 10 minutes.

- All MSF values for BRT systems also display a preference to BRT compared to on-street bus. Values range from 9 to 20 minutes with an average of around 12 minutes.

This evidence is supportive of the case that BRT has generally similar performance to light rail in the perceptions of passengers. Indeed, the average results suggest BRT may perform better than both light and heavy rail. However, the results are both scattered and limited. There are only 4 data points for BRT systems. Heavy rail data are highly skewed by the small number of negative values. Two of the three data points are extreme values and bring down the heavy rail average considerably. Removal of these points would suggest an average of 8 minutes in preference of heavy rail. Inquiries to the data source regarding the validity of these outliers suggested that a wide range of approaches to measurement are being used and may explain variations in results. The results may also be indicative of varied sample size/approach as well as of the circumstances being measured. There is a wide range in the quality and design of transit modes of all types. A run down, poorly designed, slow rail service providing low service levels may well be unfavorably perceived compared with a high-quality bus service, even if it is running on-street. A better comparison of BRT to other transit modes requires a more even-handed approach to the quality of modes being compared. The collation of a larger set of samples and a more uniform approach to measuring mode-specific factors would also improve the quality of the analysis.

It may also be appropriate to examine MSFs from an alternative viewpoint. Table 4 suggests the types of mode attributes that the MSF is representing. In general, ride quality, vehicle design, passenger amenity, and knowledge/understanding of the service offering are the major elements being represented by the MSF.

The attributes in Table 4 are divided into factors that vary with travel distance and one-off or constant value factors. Good ride quality benefits passengers traveling further (i.e., varies with distance traveled), while a quality station is only appreciated once each time it is used (it is a constant factor per trip). A more detailed modeling of mode specific factors might thus be split into mode-specific variables that vary with travel distance and mode-specific constants. This approach was suggested by Halcrow Fox (1995) and matches the views of the consultants in Transfund New Zealand (2000). 
Table 4. Suggested Transit Mode Attributes Measured in MSFs

\begin{tabular}{|c|c|c|}
\hline Attribute & Definition & Comments on Transit Mode Variation \\
\hline \multicolumn{3}{|c|}{ Factors Which Vary with Distance Traveled } \\
\hline $\begin{array}{l}\text { Vehicle } \\
\text { design, ride } \\
\text { quality, and } \\
\text { comfort }\end{array}$ & $\begin{array}{l}\text { Perceived value of } \\
\text { time within the } \\
\text { vehicle in terms of } \\
\text { ride comfort, ability } \\
\text { to read and } \\
\text { undertake other } \\
\text { activities during the } \\
\text { ride }\end{array}$ & $\begin{array}{l}\text { - Heavy rail should have advantage over light rail and BRT due to } \\
\text { smoother ride quality and greater internal vehicle space. } \\
\text { - Rail and BRT should have a benefit over on-street bus since BRT } \\
\text { systems, particularly guided bus systems, have better ride quality } \\
\text { than on-street bus. These modes also have less stop/start time } \\
\text { due to longer stop distances compared to on-street bus. }\end{array}$ \\
\hline \multicolumn{3}{|c|}{ Constant Factors } \\
\hline $\begin{array}{l}\text { Quality of } \\
\text { Stations/ } \\
\text { Stops }\end{array}$ & $\begin{array}{l}\text { Perception of the } \\
\text { quality of the } \\
\text { waiting } \\
\text { environment at } \\
\text { transit stops }\end{array}$ & $\begin{array}{l}\text { - Heavy and light rail and BRT should have similar ratings } \\
\text { depending on the extent of quality station design. } \\
\text { - All transit modes should perform better than on-street bus, since } \\
\text { the quality of the transit stops is better and facilities more } \\
\text { substantial with rail and BRT. }\end{array}$ \\
\hline $\begin{array}{l}\text { Knowledge } \\
\text { of transit } \\
\text { stop } \\
\text { location }\end{array}$ & $\begin{array}{l}\text { Perception of where } \\
\text { transit stops are } \\
\text { located both for } \\
\text { boarding and } \\
\text { alighting stops }\end{array}$ & $\begin{array}{l}\text { - There is a vast difference in passenger knowledge of the location } \\
\text { of rail stations compared to bus stops on street. } \\
\text { - The scale of station infrastructure clearly makes it easier to find } \\
\text { compared to local bus stops. } \\
\text { - This suggests that heavy and light rail and BRT should be } \\
\text { perceived broadly equally depending on the scale of the stations } \\
\text { involved. On-street bus transit stops should have a lower profile } \\
\text { compared to these transit modes. }\end{array}$ \\
\hline $\begin{array}{l}\text { Knowledge } \\
\text { of transit } \\
\text { route and } \\
\text { network } \\
\text { design }\end{array}$ & $\begin{array}{l}\text { Perception of where } \\
\text { and how transit } \\
\text { services operate. } \\
\text { The "how and what } \\
\text { to use" questions for } \\
\text { new travelers. } \\
\text { Includes } \\
\text { consideration of } \\
\text { quality of } \\
\text { information } \\
\text { provided }\end{array}$ & $\begin{array}{l}\text { - In general, high frequency systems require less timetable } \\
\text { information and hence no need to use schedules. In theory, this } \\
\text { should have an equal influence for heavy rail, light rail, and BRT, } \\
\text { although there is some evidence that BRT systems can have } \\
\text { substantially shorter headways on main line busway stations than } \\
\text { rail. } \\
\text { - Network structure is probably simpler to understand with rail- } \\
\text { based systems compared to bus. Most cities have radial rail } \\
\text { systems; hence, virtually all city dwellers would know that the } \\
\text { railway goes to the CBD. In theory, as long as the profile of BRT or } \\
\text { light rail systems is substantial, then they should also be easy to } \\
\text { understand. } \\
\text { BRT systems with substantial feeder bus to line-haul busway } \\
\text { operations may be more complex to understand. However, } \\
\text { similar issues arise for feeder bus networks to rail stations. } \\
\text { - Light and heavy rail systems have higher quality passenger } \\
\text { information systems than bus. BRT systems with similar quality } \\
\text { information systems should have similar demand performance in } \\
\text { this regard. }\end{array}$ \\
\hline
\end{tabular}


The analysis in Table 4 suggests that BRT may have at least some weaknesses compared to rail:

- Ride quality should be better with rail systems compared to BRT. However, this may not be true with guided bus systems.

- Rail vehicles can be roomier than bus vehicles.

- Rail systems can be easier to understand due to their simple network structure. However, certainly some of the larger BRT systems have simple system structures which would be as easy to understand as comparable heavy rail systems.

BRT should perform as well as rail with the other factors identified, depending on the scale of the BRT system and the quality of its stations and facilities. Primary research is clearly warranted to further explore these issues.

\section{Conclusions}

This article has sought to investigate the attractiveness of BRT compared to other transit modes from a passenger perspective. It has assembled available evidence on passenger values of trip attributes and how these values vary between transit modes. The perceived valuation of trip attributes has a major influence on passenger demand for transit system performance.

The analysis has suggested that transfer penalties and mode-specific factors are the main trip attributes that vary between transit modes. Empirical evidence has been shown to be limited in quantity and quality. No evidence of transfer penalties for BRT systems was found. However, suppositions based on available transfer penalty evidence suggest BRT systems would perform well compared to other transit modes. Evidence on mode-specific factors also supports this view.

These findings suggest that BRT systems can be as effective in attracting passengers as heavy and light rail. Since BRT has been shown to have significant cost advantages over rail, an overall cost effectiveness advantage may be claimed for BRT.

However, a major finding of this review is the need for additional research to improve the robustness of this analysis. No evidence of transfer penalty research on BRT systems was identified. A high degree of variation in the approaches used to measure transfer penalties was also identified. Adoption of a consistent approach to measure transfer penalties for a range of transit modes would pro- 
vide a more scientific framework for the comparison of transit modes. The limited number and quality of empirical measures for mode-specific factor measurement were also identified. A more consistent approach for measuring these factors is also supported.

In addition, the article theorizes that mode-specific factors should be split into constant and variable parameters. The performance of all transit modes should be assessed in terms of ride quality, vehicle design, and general perceptions of system route and network knowledge, since these may be potential weaknesses in the design of BRT compared to rail-based systems.

Finally, while this research has sought to explore how BRT might perform from a passenger attractiveness perspective, some of the findings provide useful pointers to good practices in BRT design.

- Passengers dislike transfers. Clearly designs that minimize transferring are more attractive to passengers.

- Transferring is a less significant barrier to travel when quality stations and interchange facilities are provided. BRT design should seek to emulate the quality of heavy and light rail stations in this regard. Cross platform transfers would be an example of good practice.

- The analysis has suggested that the scale of rail transit infrastructure, including stations and rights-of-way, is a significant factor in helping passengers understand how the system operates and also where transit stops are located. BRT systems will have to match the profile, scale, and simplicity of heavy rail systems to be as easy to use and understand as rail systems. The complexity of conventional bus-based systems, in terms of route structure and the large range of services offered, could be a weakness compared to rail. This needs to be addressed to achieve equivalent patronage levels to rail.

In addition, service frequency, travel speeds, and service coverage of BRT systems will need to be as extensive as light and heavy rail systems to match the patronage levels achieved by these modes.

\section{Acknowledgment}

The author would like to thank Neil Douglas and Mark Wardman for assisting with queries regarding this paper and also to Professor Bill Young for reviewing earlier 
drafts. Comments from the paper's reviewers are also appreciated. Any errors are, of course, the responsibility of the author.

\section{Endnote}

${ }^{1}$ Some values are provided for bus-bus transfers in Ottawa (Charles River Associates 1989); however, these are for transfers made prior to the full development of the busway network in Ottawa. 


\section{References}

Abelson, P.W. 1995. Cost benefit analysis of proposed major rail development in Lagos, Nigeria. Transport Reviews 15 (3): 265-289.

Algers, S., S. Hansen, and G. Tegner. 1975. Role of waiting time, comfort and convenience in modal choice for 2ork trip. Transportation Research Record 534: $38-51$.

Bray DJ \& Associates. 1995. Transport strategy for Adelaide: Background report. Working Draft Paper for SA Transport Policy Unit.

British Railways. 1989. Passenger demand forecasting handbook.

Charles River Associates. 1989. Development of a consensus paper on how transit transfers affect ridership. Draft Memorandum to Houston Metro.

Fouracre, P. R., R. J. Allport, and J. M. Thompson. 1990. The performance and impact of rail mass transit in developing countries. TRRL Research Report 278.

General Accounting Office. Mass transit-Bus Rapid Transit shows promise. Report to Congressional Requesters.

Guo, Z., and N. H. M. Wilson. 2004. Assessment of the transfer penalty for transit trips: A GIS based disaggregate modeling approach. TRB annual meeting.

Gwilliam K.M. 1999. The value of time in economic evaluation of transport projects: Lessons from recent research. World Bank Paper, Transport No OT-5.

Halcrow Fox. 1995. Metrolink extension to Oldham and Rochdale: Transportation modelling.

Horowitz, A.J., and N. A. Thompson. 1994. Evaluation of intermodal passenger transfer facilities. Federal Transit Administration DOT-T-95-02.

Hunt, J.D. 1990. A logit model of public transportation route choice. ITE Journal $60(2): 6-30$.

Kilvington, R.P. 1991. Light rail preferred to buses. Urban Transport International.

Piotrowski, S.M. 1993. Transfer penalty research. Transperth Strategic Planning \& Marketing Department.

Prosser, N., N. Douglas, and M. Jones. 1997. Development of a patronage demand model for the proposed Parramatta-Chatswood rail link. 21st Australasian Transport Research Forum. Adelaide. 
Ryan, A. 1996. The value of time. Research Note M (96) 01. London Transport Marketing.

Standeby, I. 1993. The dream: A seat on a bus that is never late! The Norwegian Trial Scheme for Public Transport. Institute of Transport Economics, Oslo.

Transit Cooperative Research Program. 2003a. Bus Rapid Transit-Volume 1-Case studies in Bus Rapid Transit. TCRP Report 90. Washington DC: Transportation Research Board.

Transit Cooperative Research Program. 2003b. Bus Rapid Transit-Volume 2Implementation guidelines. TCRP Report 90. Washington DC: Transportation Research Board.

Transfund New Zealand. 2000. Valuation of public transport attributes. Final Report. Booz Allen Hamilton for Transfund New Zealand.

Van der Waard, J. 1988. The relative importance of public transport trip-time attributes in route choice. PTRC. SAM Seminar D.

Wardman, M. 1997. Disaggregate urban mode choice models: A review of British evidence with special reference to cross elasticities. ITS Working Paper 505, University of Leeds.

Wardman, M., J. Hine, and S. Stadling. 2001. Interchange and travel choice Vol. 1. Scottish Executive Central Research Unit.

\section{About the Author}

Graham CURRIE (graham.currie@eng.monash.edu.au) is Chair in Public Transport at the Institute of Transport Studies, Monash University, Australia, where he undertakes research in transit planning and is developing postgraduate and industry programs in public transport education. He has more than 20 years of experience in transit planning and development. He was a planning officer at London Transport and also was with the Midland Metro Light Rail project in the UK. He has been a consultant and transit planning specialist for the last 16 years and has worked on transit development projects in Europe, Asia, and Australasia. Professor Currie holds a master's degree in transport planning and management from Cranfield University, UK, and a bachelor's degree in geography from Huddersfield University, UK. 